\title{
THE FOX SQUIRREL IN SASKATCHEWAN
}

\author{
C.I.G. ADAM, 2636 Argyle Street, Regina, Saskatchewan. S4S OK1
}

In 1979 an unusual tree squirrel was observed in the Regina Cemetery, a welltreed area popular with local birders. Subsequent observations showed it was a Fox Squirrel; this identification was confirmed by Robert E. Wrigley, Manitoba Museum of Man and Nature, Winnipeg, from a photograph sent to him by the author. Since then, observations have occurred in Regina and in the southeastern portion of Saskatchewan, and two specimens have been obtained.

This paper reports the Fox Squirrel specimens and gives selected sight records to 1 May, 1984. Fox Squirrels appear to have invaded Saskatchewan from Manitoba and North Dakota, and they will probably continue to do so, paralleling the situation in other provinces and states. Due to its secretive nature, this species may have gone undetected in the province for several years. The purpose of this paper is to alert Saskatchewan residents to the presence of this relatively new species, and to speculate on means of its arrival and dispersal.

\section{Regina Sightings}

There have been many Fox Squirrel sightings in Regina since 1979, culminating in the observation of an adult attending young in 1984 .

The first observation known to the author occurred on 10 November, 1979 , in the Regina Cemetery (B. Luterbach, pers. comm. Luterbach also says that the cemetery caretakers saw the squirrels in the fall of 1978.) Observations continued in the Regina Cemetery, with two squirrels recorded in May 1980, and one in the spring of 1981 . Squirrels were not seen in this location after this date.

In summer $1980 \mathrm{~J}$. Jowsey and F. Brazier (pers. comm.) observed a Fox Squirrel in a grove of trees northwest of the Legislative Building. On 13 May 1981, T. Riffel (pers. comm.) observed a squirrel in the same location sunning itself on a branch $6 \mathrm{~m}$ from a leaf nest.

In fall 1983 a Fox Squirrel was observed south of the Legislative Building in the vicinity of the tennis courts (Fig. 1). By its description it was identified as a Fox Squirrel by Wrigley (pers. comm.). Two squirrels were seen together at the tennis courts; single squirrels were observed in 1983 crossing College Avenue in the vicinity of the Saskatchewan Museum of Natural History, a distance of at least 1 $\mathrm{km}$ from the tennis courts (J. Jowsey, B. Luterbach, pers. comm.).

On 30 April and 1 May 1984, in a spruce tree at the tennis courts behind the Legislative Building, an adult was observed attending three young squirrels that appeared by their hesitant actions, to have recently left the nearby grass nest ( $T$. Riffel, pers. comm.). The young squirrels were almost the same size as the adult, but differed in having sparselyfurred tails. This is the first evidence of the Fox Squirrels breeding in the province.

Fox Squirrels have also been recorded (as tracks) on Christmas Mammal Counts in 1979, 1980 and again in $1983 .{ }^{4}{ }^{5} 6$

\section{Saskatchewan Specimens}

Two specimens have been received by the Saskatchewan Museum of Natural History (SMNH) in Regina. The first (SMNH \# 13101) was donated by $S$. Barber of the Saskatchewan Parks and Renewable Resources, Wildlife Branch, 12 December, 1980. The specimen is a male collected at Oxbow, on the Souris River, by an unknown individual. Measurements are: total length $-508 \mathrm{~mm}$; tail $-225 \mathrm{~mm}$; weight $-727 \mathrm{~g}$. This is the 


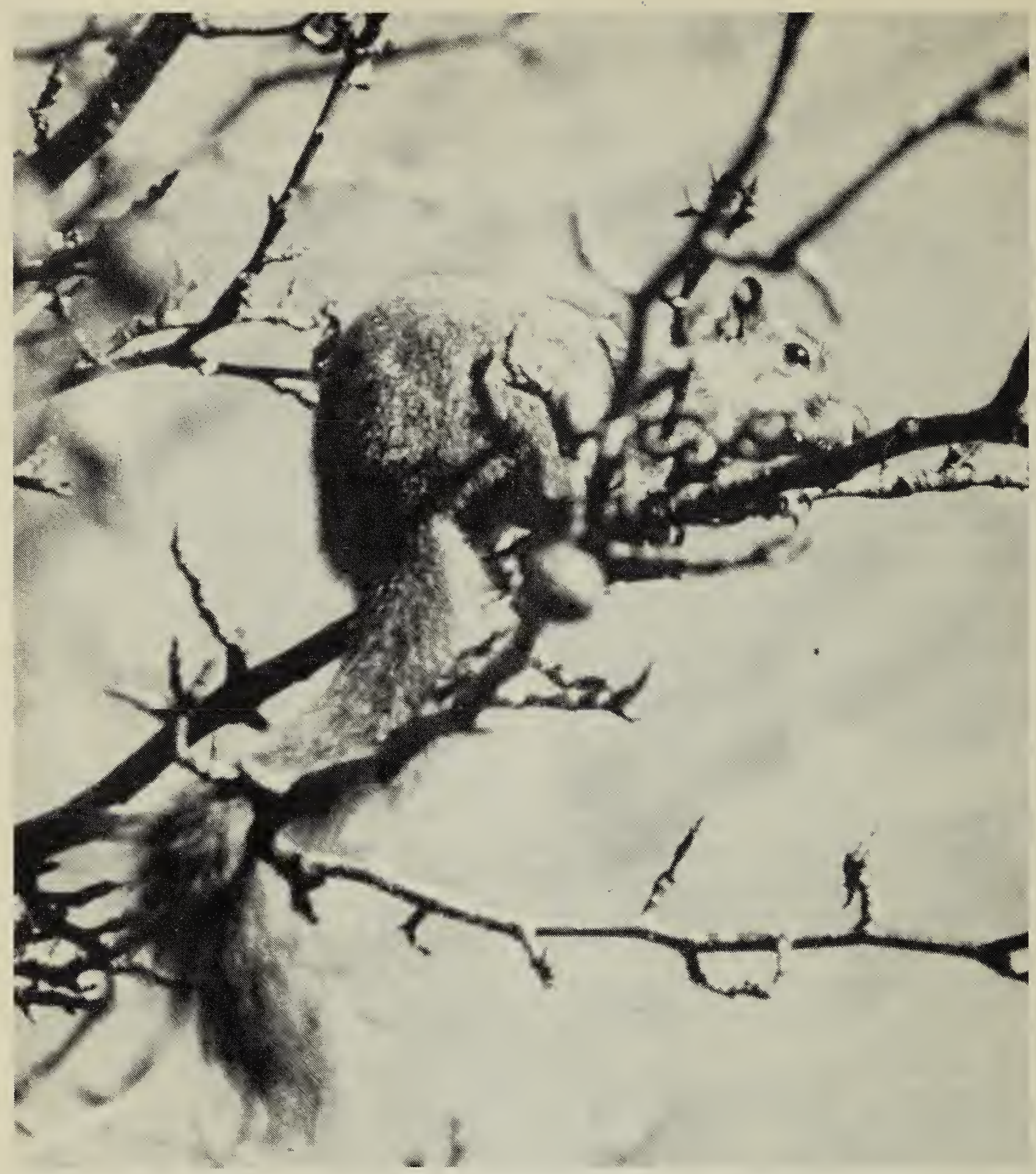

Figure 1. Fox Squirrel behind the Legislative Building, Regina, fall 1983.

Jon Triffo

first official specimen for Saskatchewan.

The second specimen (SMNH \# 13490 ) is a cased skin donated in May 1983 by R. Beaulieu, Regional Biologist for the Hudson Bay Region. The skin was obtained from a trapper in the vicinity of Stove Creek, $26.5 \mathrm{~km}$ east of Kelvington, on the southwestern edge of the Porcupine Provincial Forest. The trapper has apparently seen a number of other Fox Squirrels there. The specimen was prob- ably trapped in the winter of $1982-83$ (R. Beaulieu, pers. comm.).

The author has examined both specimens and they are identical in appearance to the Regina squirrels.

\section{Other Saskatchewan Sightings}

Besides the Stove Creek and Oxbow specimens, there are a number of sight records. From Osage (on Highway 33, approximately $88 \mathrm{~km}$ southeast of Regina) came a report of a Fox Squirrel 
electrocuted on a power line in the summer of 1983 (W. Russon, pers. comm.). R. Longmuir, Conservation Officer at Moose Mountain Provincial Park reports that Fox Squirrels apparently inhabit the Souris River valley as far west as Estevan. Longmuir states that he has seen several squirrels in the valley (pers. comm.) R. Kreba observed a Fox Squirrel at Weyburn 21 May 1979 and, in March 1984 several leaf nests in that city and along the Souris River to Estevan (pers. comm.). (Weyburn is situated on the upper reaches of the Souris River.) R. Tillie and D. Pingert have observed large numbers of Fox Squirrels at a campground near Roche Percee, on the Souris River east of Estevan (D. Baron, pers. comm.).

\section{Adjacent Provinces and States}

The Fox Squirrel's formerly recorded range was the eastern half of the continental United States, from Texas to Florida, north to the Great Lakes, and west to North Dakota. ${ }^{2}{ }^{12}$ The species was introduced to Pelee Island, Lake Erie, Ontario in the 1890's, and a small population continues to flourish there. Pelee Island has long been the only known Canadian outpost of this species.

Manitoba's first Fox Squirrel, in fact the first official Canadian non-introduced specimen, was obtained near St. Claude, 97 km west of Winnipeg, 1 July 1972 (Figure 2). ${ }^{14}$ Two more specimens were obtained in 1977 (Mariapolis and Riverton), ${ }^{13}$ but since then, "almost two dozen" specimens have been received at the Manitoba Museum of Man and Nature, including one from the Lyleton area, near the Souris River and close to the Saskatchewan border (R. Wrigley, pers. comm.). There have also been a number of sight records.

Fox Squirrels have invaded Manitoba probably from North Dakota, and have now been firmly established for some time in the southwestern portion of that province. Wrigley feels that the Fox Squirrel will probably continue its expan- sion in a northwest direction within the oak-maple-ash habitat. ${ }^{13}$

Fox Squirrels first invaded North Dakota in the early 1930's from Minnesota via the Missouri River. ${ }^{8}$ Over a period of 20 years the species spread up the major tributaries of the Missouri River where its range was confined to areas with sufficient tree growth. The natural spread was also augmented by several introductions. The current range is now almost statewide and the habitat presently occupied is riparian cottonwood forests and town parks. ${ }^{3}$

An examination of Fox Squirrel range maps shows trends to northwestern expansion. ${ }^{2} 312$ The spread corresponds mostly to deciduous forest along the major river systems. One notable extension occurs along the Yellowstone River for about $250 \mathrm{~km}$ southwestward from the Missouri River into the Billings, Montana, area. ${ }^{9} 10$ However, the species has failed to spread along the upper Missouri and Milk Rivers of northern Montana where dams have destroyed the cottonwood forests of the floodplains of these valleys. ${ }^{9}$

In Michigan, the spread of the Fox Squirrel in the 1800's and early 1900's was associated with the decline of the Gray Squirrel. ${ }^{1}$ The Fox Squirrel spread northward in Michigan with the clearing of land for agriculture. Thus the Gray Squirrel, which preferred deep woods, was replaced in some areas by the Fox Squirrel, which selected woodland edges. Today, both species are common across Michigan.

\section{The Spread Into Saskatchewan}

As in Manitoba and the northern United States, the Fox Squirrel is invading Saskatchewan along the river systems, namely the Souris from North Dakota and Manitoba (the Oxbow specimen), and the Assiniboine from Manitoba (the Stove Creek specimen), and possibly along the Qu'Appelle and its tributaries. The lower Assiniboine and eastern Qu'Appelle River 


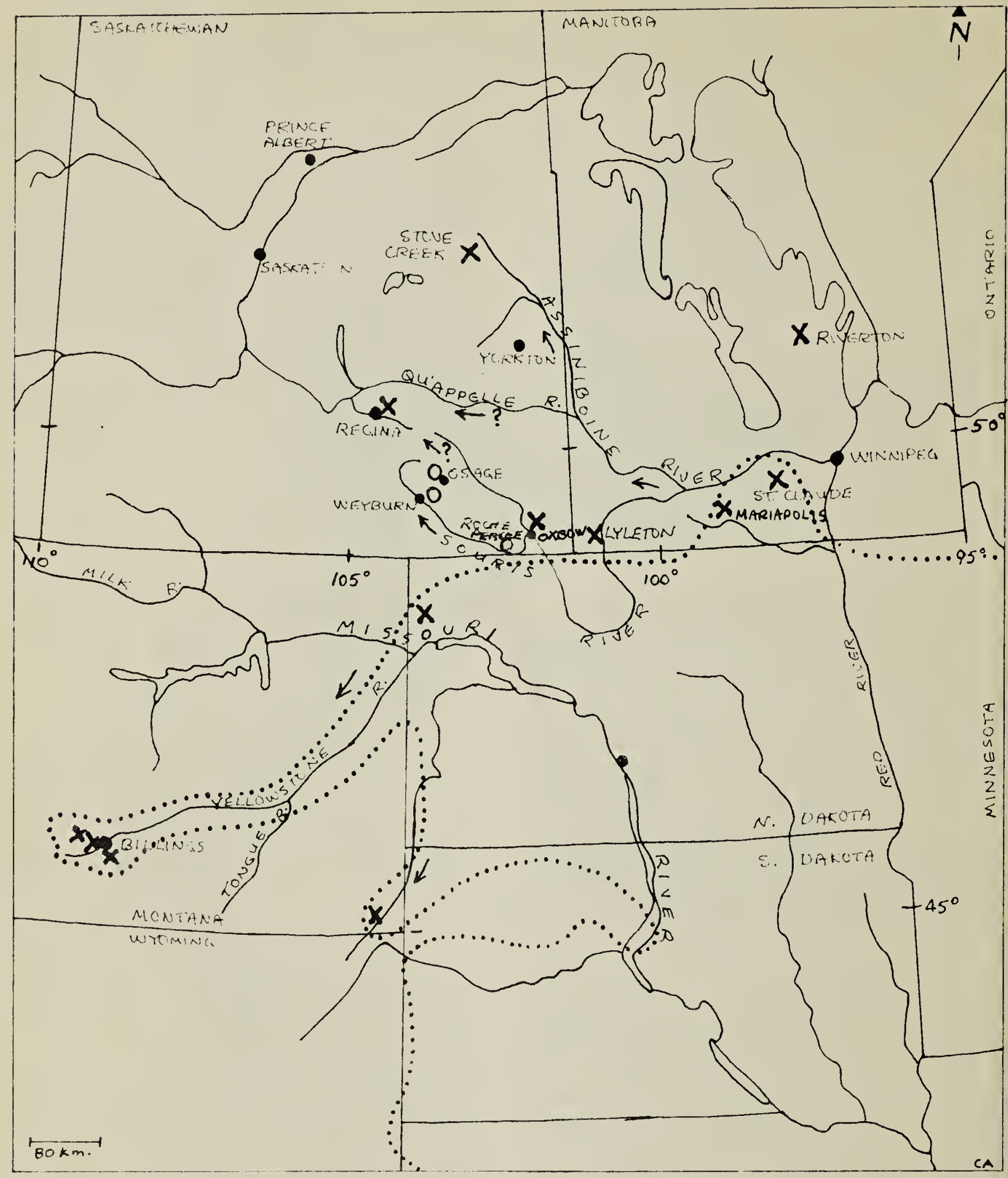

Figure 2. Distribution of the Fox Squirrel, range . . (after Ha/ß $). X$ - specimens and confirmed sightings. $\mathrm{O}-$ unconfirmed sightings. $\rightarrow-$ invasion routes. (Not all Manitoba records included.)

lie within the Aspen - Bur Oak Ecodistrict which extends along the Qu'Appelle as far west as Fort Qu'Appelle and along the Assiniboine as far north as Togo. ${ }^{7}$ The Stove Creek specimen indicates that the Fox Squirrel has spread beyond the limits of this ecodistrict and well into the Aspen Grove and Mixedwood Ecodistricts. ${ }^{7}$ Stove Creek is $10 \mathrm{~km}$ west of the northern extent of the Assiniboine River. Assuming this is a natural occurrence and not an introduction, there is reason to expect that the Fox Squirrel will continue to expand its range westward along the edge of the Mixedwood Ecodistrict.

The Regina squirrels may have arrived by travelling westwards along the wooded 
Qu'Appelle River valley and then south and east via Wascana Creek, which is a wooded valley to within $11 \mathrm{~km}$ of the city (Figure 2). These squirrels, if an introduction is ruled out, may also have arrived from the southeast via the Souris River, and Moose Mountain and Wascana Creeks, although the habitat is not suitable along most of the upper reaches. To make the jump between creeks would have required the squirrels to cross many kilometres of the treeless Regina Plain, but as they seem capable of doing this (R. Wrigley, pers. comm.), this arrival route may not seem so implausible.

In North Dakota, Fox Squirrels were seen as much as $80 \mathrm{~km}$ from suitable habitat, and there are many reports of squirrels in isolated shelterbelts. ${ }^{8}$ Fox Squirrels are residents of the transition zone between the forest and the prairie; the barriers to their advancement in Saskatchewan appear to be large areas of treeless prairie. Introductions by man in any of the above areas in Saskatchewan cannot be ruled out.

\section{Physical Characteristics}

The Fox Squirrel is a large, heavyset tree squirrel, much larger than the more familiar Red Squirrel, and slightly larger than the Gray Squirrel. ${ }^{12}$ The subspecies in the northern portion of its continental range is Sciurus neger rufiventer. ${ }^{3}$ Average size is $54 \mathrm{~cm}$ (21 in.) with a tail about half that length. The tail of a Red Squirrel makes up about three quarters of the total length. Like the Gray Squirrel, the Fox Squirrel has three commonly occurring colour phases, red or buff, black and gray, one of which usually predominates in an area. ${ }^{3}$ The Fox Squirrels here are of the red phase, and are blackish-gray and orange on the back, with orange underparts and legs. Gray Squirrels, which are about the same proportions (half tail) are gray or black above and white or orangey-brown beneath (making confusion with the Fox Squirrel possible (R. Wrigley, pers. comm.). The Red Squirrel has white to gray underparts and a white eye-ring, with orange-red to olive brown back, sides of cinnamon and a summer flank stripe of black.

The tail of the Fox Squirrel is bushy with orange-tipped hairs, each guard hair having a black sub-terminal band. The orange-tipped guard hairs are a good field mark, since the Gray Squirrel always has white-tipped guard hairs on the tail. Tails of Red Squirrels are rufous-red above and gray below with a black band near the tip.

Fox Squirrels prefer forest edges and parkland areas, woodlots and city parks. Although they have adapted to city parks the Gray Squirrel seems to prefer deep woods to the forest edge.

\section{Behaviour and Habits}

The Regina Fox Squirrels are secretive in nature and are often difficult to approach. In most encounters, if seen at all, they will stop what they are doing, move to the trunk of a tree and freeze flatly against it, pointing upward with tail extended. They will move around the trunk in this position in response to the observer's movements, keeping to the opposite side of the trunk. Eventually they may bound away from tree to tree until their leaf nest is reached, where they may disappear for a long period of time. The freezing behaviour was observed at both Regina Cemetery and the Legislative grounds. (Fig. 3).

All three species of diurnal tree squirrel can inhabit large leaf and twig nests in summer and natural cavities in trees in winter; the Red Squirrel also inhabits ground burrows in the northern part of its range. ${ }^{2}$

Observers are invited to submit Fox Squirrel observations to the author and to the Saskatchewan Museum of Natural History to aid in determination of the range of this species in Saskatchewan.

\section{Acknowledgements}

Helpful suggestions, data, and a review of this paper were provided by R. Wrigley 
of the Manitoba Museum of Man and Nature in Winnipeg. Tom Riffel, and Saskatchewan Museum of Natural History staff members Dave Baron and Robert Kreba also provided data and comments. Bob Luterbach and Tom Riffel of Regina provided observations of the Regina squirrels dating back to 1979 .

1 ALLEN, D.L. 1943. Michigan Fox Squirrel management. Game Div., Dept. Conser., Lansing, Mich.

2 BANFIELD, A.W.F. 1974. The mammals of Canada. Univ. of Toronto Press, Toronto, Ont.

${ }^{3}$ HALL, E.R. 1981. The mammals of North America. vol I. Second Ed. John Wiley and Sons, New York.

${ }^{4}$ HARRIS, W.C. 1980 . Saskatchewan Christmas Mammal Count - 1979. Blue Jay 38:53-55.

${ }^{5}$ HARRIS, W.C. 1981. Saskatchewan Christmas Mammal Count - 1980. Blue Jay 39:54-57.

${ }^{6}$ HARRIS, W.C. 1984. Saskatchewan Christmas Mammal Count - 1983. Blue Jay 42:55-60.

7 HARRIS, W.C., A. KABZEMS, A.L. KOSOWAN, G.A. PADBURY and J.S. ROWE. 1983. Ecological regions of Saskatchewan. Sask. Parks and Renewable Resources, Forestry Div. Tech. Bull. No. 10.

${ }^{8}$ HIBBARD. E.A. 1956. Range and spread of the Gray and Fox squirrels in North Dakota. Jour. Mamm. 37:525-531.

${ }^{9}$ HOFFMANN, R.S., P.L. WRIGHT and F.E. NEWBY. 1969. The distribution of some mammals in Montana. I. Mammals other than bats. Jour. Mamm. 50:579-604.

${ }^{10}$ LAMPE, R.P., J.K. JONES, R.S. HOFF. MANN and E.C.BIRNEY. 1974. The mammals of Carter County, southeastern Montana. Univ. Kansas Mus. Nat. Hist., Occ. Paper no. 25:1-39.

11 NERO, R.W. and R.E. WRIGLEY. 1977. Rare, endangered and extinct wildlife in Manitoba. Manitoba Naturalist 18:4-37.
12 WOODS, S.E. Jr. 1980. The squirrels of Canada. Nat. Mus. of Canada, Ottawa.

${ }^{13}$ WRIGLEY, R.E. 1979. History of the mammal fauna of southern Manitoba. Manitoba Nature 20:3-17.

${ }^{14}$ WRIGLEY, R.E., H.E. DRESCHER and S. DRESCHER. 1973. First record of the Fox Squirrel in Canada. Jour. Mamm. 54:782-783.

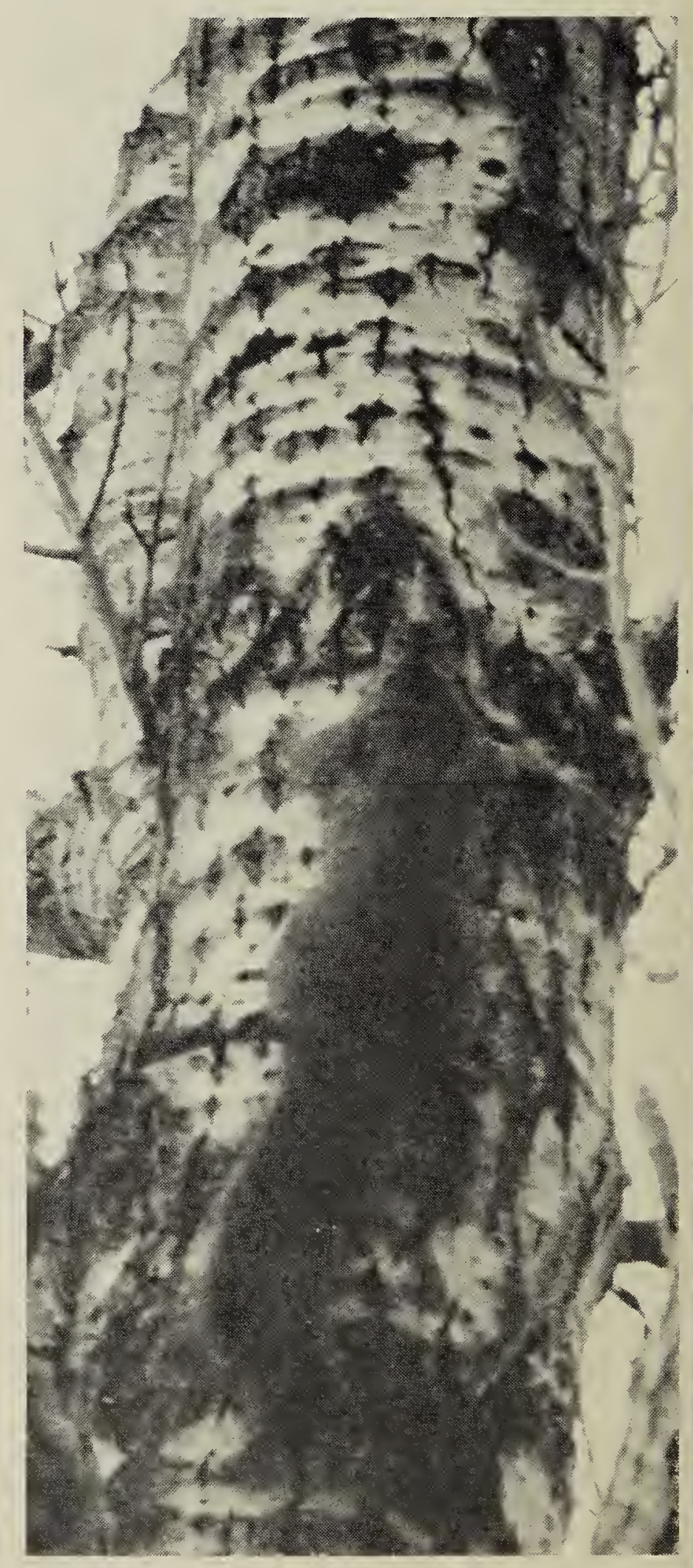

Figure 3. Typical freezing posture of Fox Squirre!

C.I.G. Adam 